\title{
ANATOMICAL STUDY OF NUTRIENT FORAMEN IN THE LONG BONES OF UPPER EXTREMITIES
}

\author{
Dr. Jawid Azizi \\ Lecturer in Anatomy Department \\ Medical Faculty \\ Kabul University of Medical Sciences \\ Kabul, Afghanistan
}

\author{
Dr. Hidayatullah Danish \\ Lecturer in Anatomy Department \\ Medical Faculty \\ Kabul University of Medical Sciences \\ Kabul, Afghanistan
}

\begin{abstract}
The aim of the present study is to observe number of foramina on the shaft of a bone, to observe surface on which it was located and to observe Location in relation with length of the shaft.

This study was conducted in 80 long bones of the upper limb (40- humerus, 20 - radius, and 20 -ulna). The number and position of the diaphysis nutrient foramen in each of the long bones were noted.

The result of the study shows, that in humerus single nutrient foramen was present in $85 \%$ of the bones, double nutrient foramina in $15 \%$ of the bones. The most common location of the nutrient foramina in humerus was in Antero medial surface, which was noted in $40 \%$ of the bones and in $80 \%$ of the bones the nutrient foramen was located in the middle third of the shaft of humerus. In radius, single nutrient foramen was found in $90 \%$ of the bones and double nutrient foramina were found in $\mathbf{1 0 \%}$ of the bones. The most common location of the nutrient foramen in radius was on the anterior surface, which was noted in $70 \%$ of the bones and in $60 \%$ of the bones, the nutrient foramen was located in the middle third of the shaft of radius. In ulna, single nutrient foramen was found in $95 \%$ of the bones and double nutrient foramina were found in $5 \%$ of the bones. The most common location of the nutrient foramen in ulna was on the anterior surface, which was noted in $60 \%$ of the bones and in $80 \%$ of the bones the nutrient foramen was on the middle third of the shaft of ulna.

To conclude the result we can say, that the precise anatomical knowledge of the nutrient foramen of the long bones of upper limb is important for orthopedic surgeons during surgical procedures like bone grafting, microsurgical bone transplantation.
\end{abstract}

Keywords: Nutrient Foramen, Long Bones, Variation in Position, Location, Number

\section{INTRODUCTION}

Nutrient foramen is an opening in the bone shaft which gives passage to the blood vessels of the medullary cavity of a bone for its nourishment and growth [1]. The nutrient artery is the principal source of blood supply to a long bone and is particularly important during its active growth period in the embryo and fetus, as well as during the early phase of ossification [2]. The nutrient artery enters individual bones obliquely through a nutrient foramen [3].Nutrient foramen is directed towards elbow in upper limb (directed towards lower end of humerus and upper ends of radius and ulna). This is said to be due to one end of limb bones growing faster than the other and generally follows the rule, "to the Their positions in mammalian bones are variable and may alter during the growth phase.

The topographical knowledge of these nutrient foramina is useful in operative procedures to preserve the circulation.[46] Humphrey was working on the direction and obliquity of nutrient canals postulated periosteal slipping theory, the canal finally directed away from the growing end. [7]. Nutrient artery is the major source of blood supply to the bone and hence plays an important role in fracture healing.

Orthopedic surgical procedures like vascularized bone microsurgery requires the detailed knowledge of the blood supply. In free vascular bone grafting, the blood supply by nutrient artery is extremely important and must be preserved in order to promote fracture healing [8]. Study of nutrient foramina in upper limb is very important for morphological, clinical, and pathological point of view. Fracture healing or hematogenic osteomyelitis is closely related to the vascular system of the bone. [9] Detailed data on the blood supply to the long bones is invariably crucial in the development of new transplantation and resection techniques in orthopedics [2, $10]$.

\section{MATERIALS AND METHOD}

The present study was conducted in the Department of Anatomy, Kabul University of Medical Sciences. This study was approved by the academic and Institutional research and ethics committee.

The materials for the present study consisted of 80 adult human cleaned and dried bones of the upper limbs. They were divided into three groups: 35 bones of humerus and 25 bones radius and 20 of ulna. All selected bones were normal with no appearance of pathological changes. 


\section{OBJECTIVES}

To observe number of foramina on the shaft of a bone, to observe Surface on which it was located, to observe Location in relation with length of the shaft. The nutrient foramina were observed in all bones with the help of a hand lens. They were identified by their elevated margins and by the presence of a distinct groove proximal to them.

\section{POSITION OF NUTRIENT FORAMINA}

The distance of the dominant nutrient foramen (DNF) from the highest point of the proximal part of the long bones was measured with Vernier calipers. The total length (TL) of the bone was measured using an osteometric board. The position of all nutrient foramina was determined by calculating the foraminal index (FI) using the formula:

$\mathrm{FI}=(\mathrm{DNF} / \mathrm{TL}) \times 100$

Where $\mathrm{DNF}=$ the distance from the proximal end of the bone to the nutrient foramen; TL=Total bone length [11].

The position of the foramina was divided into three types according to FI as follows:

\section{Type 1:}

FI below 33.33, the foramen was in the proximal third of the bone.

Table 1: Position of nutrient foramina

\begin{tabular}{|l|l|l|l|}
\hline \multirow{2}{*}{ Bones } & \multicolumn{2}{|l|}{ Position } \\
\cline { 2 - 4 } & Type 1 & Type 2 & Type3 \\
\hline Humerus & - & $32(80 \%)$ & $8(20 \%)$ \\
\hline Radius & $8(40 \%)$ & $12(60 \%)$ & - \\
\hline Ulna & $4(20 \%)$ & $16(80 \%)$ & - \\
\hline
\end{tabular}

Type 2:

FI from 33.33 up to 66.66 , the foramen was in the middle third of the bone.

Type 3:

FI above 66.66, the foramen was in the distal third of the bone. All the observations were statistically analyzed using Microsoft excel worksheet.

\section{Results}

Number of nutrient foramina observed: In humerus, single nutrient foramen was observed in $85 \%$ of the bones, double nutrient foramina were observed in $15 \%$ of the bones (Table 1).

Table 2: Number of nutrient foramina in long bones of the upper limb.

\begin{tabular}{|c|c|c|}
\hline Bones & $\begin{array}{c}\text { Number of } \\
\text { foramina }\end{array}$ & $\begin{array}{c}\text { Number of } \\
\text { bones (\%) }\end{array}$ \\
\hline Humerus N=40 & 1 & $34(85)$ \\
\hline
\end{tabular}

\begin{tabular}{|ll|c|c|}
\hline & & 2 & $6(15)$ \\
\hline Radius & $\mathbf{N = 2 0}$ & 1 & $18(90)$ \\
& & 2 & $2(10)$ \\
\hline Ulna & $\mathbf{N}=\mathbf{2 0}$ & 1 & $19(95)$ \\
& & 2 & $1(5)$ \\
\hline
\end{tabular}

In radius, single nutrient foramen was observed in $90 \%$ of the bones and double nutrient foramina were observed in $10 \%$ of the bones (Table 1).

In ulna, single nutrient foramen was observed in $95 \%$ of the bones, double nutrient foramina were observed in $5 \%$ of the bones (Table 1).

Table 3: Position of nutrient foramina in the humerus

\begin{tabular}{|c|c|}
\hline Position & $\begin{array}{c}\text { Number of } \\
\text { foramina }(\boldsymbol{\%})\end{array}$ \\
\hline Antero medial surface & $32(40)$ \\
\hline Medial border & $6(15)$ \\
\hline Posterior surface & $1(2.5)$ \\
\hline Anterior border & $1(2.5)$ \\
\hline
\end{tabular}

Nutrient foramina in humerus: $80 \%$ of the nutrient foramina were most commonly present in the middle one third of the humerus bone (Table 2).40\% of the nutrient foramina were most commonly located in the anteromedial surface (Table 3).

\begin{tabular}{|} 
Table 4: Position of nutrient foramina in Radius \\
\begin{tabular}{|c|c|}
\hline Position & $\begin{array}{c}\text { Number of } \\
\text { foramina (\%) }\end{array}$ \\
\hline Anterior surface & $14(70)$ \\
\hline Medial surface & $4(20)$ \\
\hline Anterior border & $1(5)$ \\
\hline Posterior surface & $1(5)$ \\
\hline
\end{tabular}
\end{tabular}

Nutrient foramina in radius: $60 \%$ of the nutrient foramina were most commonly present in the middle one third of the radius bone. (Table 2 ). $70 \%$ of the nutrient foramina were most commonly located in the anterior surface (Table 4) 
Table 5: Position of NF in the ulna.

\begin{tabular}{|c|c|}
\hline Position & $\begin{array}{c}\text { Number of } \\
\text { foramina (\%) }\end{array}$ \\
\hline Anterior surface & $12(60)$ \\
\hline Medial border & $6(30)$ \\
\hline Posterior surface & $1(5)$ \\
\hline Anterior border & $1(5)$ \\
\hline
\end{tabular}

Nutrient foramina in ulna: $80 \%$ of the nutrient foramina were most commonly present in the middle one third of the ulna bone.(Table2).60\% of the nutrient foramina were most commonly located in the anterior surface (Table 5).

\section{Discussion}

Number of Nutrient Foramina: In our study, a single nutrient foramen had a higher percentage $(85 \%)$ in the humeral bones, compared to that of double (15\%).Many studies reported a percentage approximately similar to that of the present result $[12,5]$. The range of occurrence of double foramina varied from $13 \%$ [13]to $26 \%$ [14] and $42 \%$ [5]. In the present study total $90 \%$ of the radius examined had a single nutrient foramen (Table 1). In other studies, the majority of radii more than $90 \%$ were found to possess a single nutrient foramen $[2,16]$.

The absence of nutrient foramina in the long bones is well known.[5,15,16] In the present study, we did not found any radii with the absence of the nutrient foramina.

Gotzen, $\mathrm{N}$ et al and Gumusburun, E et al $[17,18]$ were noted a single nutrient foramen in more than $94 \%$ of ulnae. This corresponds with the observations in the ulnae in the present study (Table 1)

Position of Nutrient Foramina: In our study, most of nutrient foramina were located along the middle third of the humerus (Table 2) which was correlated with other studies $[2,19,20]$ Also, $40 \%$ of all humeral nutrient foramina were observed on the anteromedial surface of the bone (Table3). Similar findings had been reported by Kizilkanat et al. [2] ,Kumar et al [14], and Ukoha Ukoha Ukoha et al [21]. Mysoreker VR[5] and Caroll SE [22] in their studies stated that surgery or fracture in distal and middle $1 / 3$ of the shaft of the humerus leads to the poor healing compared to fracture of proximal half of the bone which is unlikely to compromise the blood supply.

In our study, $60 \%$ of the total nutrient foramina were noted most often in the middle third of the radius and $40 \%$ were in the proximal third. No nutrients foramina were detected in the distal third of radius (Table 2). The ratios of the present study were close to those reported by Mysorekar (1967) who found $62 \%$ of foramina located in the middle third of the bone and $36 \%$ in the proximal end [5]. Similar findings had been reported by Anusha $\mathrm{P}$ et al [23].In the present study, $70 \%$ of all radial foramina were on the anterior surface, of the bone. Such results were in accordance with the previous studies [19] who stated that the majority of nutrient foramina were located on the anterior surface of the bone. In the present study, the majority of nutrient foramina $(80 \%)$ were in the middle third while $20 \%$ were in the proximal third of the ulna bone (Table 2). No nutrient foramina were detected in the distal third of the ulnae. Some authors reported that the majority of nutrient foramina were located in the middle third [5] while others stated that most of foramina were in the proximal third $(13,14)$. Also, $60 \%$ of the nutrient foramina were located on the anterior surface of the ulnae (Table 5). In all previous studies, the nutrient foramina were mostly observed on the anterior surface of the ulna $[2,10]$.

\section{CLINICAL RELEVANCE}

An understanding of the position and number of the nutrient foramina in long bones is important in orthopedic surgical procedures such as joint replacement therapy, fracture repair, bone grafts and vascularized bone microsurgery [2].

The foramen may be a potential area of weakness in some patients and, when under stress because of increased physical activity or decreased quality of the bone, the foramen may allow development of a fracture. Position of the fracture relative to the nutrient foramen of the long bone and the patterns of edema are the secondary signs in the key of the diagnosis of this type of fracture [25].

\section{CONCLUSION}

The study confirmed previous reports regarding the number and position of the nutrient foramina in the long bones of the limbs.

It also provided important information to the clinical significance of the nutrient foramina. The anatomical data of this subject is enlightening to the clinician as the micro vascular bone transfer is becoming more popular.

\section{ACKNOWLEDGMENT}

This research was supported by Anatomy department of Kabul University of Medical Sciences. We thank our colleagues from the department who provided insight and expertise that greatly assisted the research.

\section{REFERENCES}

[1]. Malukar, O., \& Joshi, H. (2011). Diaphysial nutrient foramina in long bones and miniature long bones. Lateral, 12, 84.

[2]. Kizilkanat, E., Boyan, N., Ozsahin, E. T., Soames, R., \& Oguz, O. (2007). Location, number and clinical significance of nutrient foramina in human long bones. Annals of Anatomy-Anatomischer Anzeiger, 189(1), 87-95.

[3]. Henderson, R. G. (1978). The position of the nutrient foramen in the growing tibia and femur of the rat. Journal of anatomy, 125(Pt 3), 593.

[4]. Henderson, R. G. (1978). The position of the nutrient foramen in the growing tibia and femur of the rat. Journal of anatomy, 125(Pt 3), 593. 


\section{International Journal of Engineering Applied Sciences and Technology, 2019 \\ Vol. 4, Issue 6, ISSN No. 2455-2143, Pages 7-10 \\ Published Online October 2019 in IJEAST (http://www.ijeast.com)}

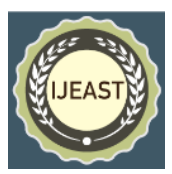

[5]. Mysorekar, V. R. (1967). Diaphysial nutrient foramina in human long bones. Journal of anatomy, 101(Pt 4), 813.

[6]. Serafin, D., Buncke Jr, H. J., \& Snyder, C. C. (1979). Microsurgical composite tissue transplantation. Plastic and Reconstructive Surgery, 64(3), 397.

[7]. Harris, H. A. (1933). Bone Growth in Health and Disease: The biological principles underlying the clinical, radiological, and histological diagnosis of perversions of growth and disease in the skeleton. Oxford University Press; London.

[8]. Yaseen, S., Nitya, W., \& Ravinder, M. (2014). Morphological and topographical study of nutrient foramina in adult humerii. International journal of innovative research and development, 3, 7-10.

[9]. Skawina, A., \& Wyczolkowski, M. (1987). Nutrient foramina of humerus, radius and ulna in Human Fetuses. Folia morphologica, 46(1-2).

[10]. Kirschner, M. H., Menck, J., Hennerbichler, A., Gaber, O., \& Hofmann, G. O. (1998). Importance of arterial blood supply to the femur and tibia for transplantation of vascularized femoral diaphyses and knee joints. World journal of surgery, 22(8), 845-852.

[11]. Shulman, S. S. (1959). Observations on the nutrient foramina of the human radius and ulna. The Anatomical Record, 134(4), 685-697.

[12]. Campos, F. F., Pellico, L. G., Alias, M. G., \& Fernandez-Valencia, R. (1987). A study of the nutrient foramina in human long bones. Surgical and Radiologic Anatomy, 9(3), 251-255.

[13]. Longia, G. S., Ajmani, M. L., Saxena, S. K., \& Thomas, R. J. (1980). Study of diaphyseal nutrient foramina in human long bones. Cells Tissues Organs, 107(4), 399-406.

[14]. Kumar, S., Kathiresan, K., \& Gowda, M. S. T. (2012). Nagalaxmi. Study of Diaphysial Nutrient Foramina In Human Long Bones. Anatomica Karnataka, 6(2), 66-70.

[15]. Lütken, P. (1950). Investigation into the position of the nutrient foramina and the direction of the vessel canals in the shafts of the humerus and femur in man. Cells Tissues Organs, 9(1-2),

57-68.

[16]. Murlimanju, B. V., Prashanth, K. U., Prabhu, L. V., Saralaya, V. V., Pai, M. M., \& Rai, R. (2011). Morphological and topographical anatomy of nutrient foramina in human upper limb long bones and their surgical importance. Rom J Morphol Embryol, 52(3), 859-862.. [17]. Götzen, N., Cross, A. R., Ifju, P. G., \& Rapoff, A. J. (2003). Understanding stress concentration about a nutrient foramen. Journal of biomechanics, 36(10), 1511-1521.

[18]. Guemuesburun, E., Adiguzel, E., Erdil, H., Ozkan, Y., \& Gulec, E. (1996). A study of the nutrient foramina in the shaft of the fibula. Okajimas folia anatomica Japonica, 73(23),

125-127.
[19]. Nagel, A. (1993). The clinical significance of the nutrient artery. Orthopaedic review, 22(5), 557-561.

[20]. Patel, S. M., \& Vora, R. K. (2015). Anatomical study of nutrient foramina in long bones of human upper limbs. IAIM, 2(8), 94-98.

[21]. Ukoha, U. U., Kosisochukwu, E. U., Henry, C. N., Damian, N. E., Obioma, C. E., \& Izuchukwu, F. O. (2013). A study of nutrient foramina in long bones of Nigerians. Tech orthop, 2, 304-8.

[22]. Carroll, S. E. (1963). A study of the nutrient foramina of the humeral diaphysis. The Journal of bone and joint surgery. British volume, 45(1), 176-181. [23]. Anusha, P., \& Naidu, M. P. (2013). A study on the nutrient foramina of long bones. J Med Sci Technol, 2(3), $150-7$.

[24]. Craig, J. G., Widman, D., \& van Holsbeeck, M. (2003). Longitudinal stress fracture: patterns of edema and the importance of the nutrient foramen. Skeletal radiology, 32(1), 22-27..

in the human innominate. Human Evolution, 1(3), 221-231.

[25]. Okoseimiema, S. C., \& Udoaka, A. I. (2013). Radiologic determination of ischiopubic index in south-south Nigerian population. Asian Journal of Medical Sciences, 5(5), 96-100. 